Fetal Diagnosis

and Therapy
Fetal Diagn Ther 2008;23:160

DOI: $10.1159 / 000111601$
Received: December 18, 2006

Accepted: February 22, 2007

Published online: November 26, 2007

\title{
Definition of Pentalogy of Cantrell
}

\section{Commentary on Araujo Júnior et al: Diagnosis of Pentalogy of Cantrell by Three-Dimensional Ultrasound in Third Trimester of Pregancy (Fetal Diagn Ther 2006;21:544-547)}

\author{
Jean-Martin Laberge \\ Montreal Children's Hospital, McGill University Health Centre, Montreal, Que., Canada
}

I read with interest the article by Araujo et al., published in Fetal Diagnosis and Therapy, volume 21. [1]. The paper is interesting and useful; however, the definition of pentalogy of Cantrell given by the authors needs to be corrected. Both in the abstract and the introduction, the authors state that ectopia cordis is a component of the pentalogy, and in the discussion they mention omphalocele as 'other anomalies that may be associated'. The five elements of the pentalogy as described in Cantrell's initial paper and cited in recent pediatric surgery textbooks [2] are as follows:

(1) supraumbilical omphalocele,

(2) lower sternal cleft,

(3) defect in the central tendon of the diaphragm,
(4) defect in the pericardium,

(5) intracardiac anomaly.

The pentalogy is also referred to as a 'cephalic fold defect' or 'cephalic fold omphalocele'.

Ectopia cordis is a defect where the heart typically protrudes between the two halves of the split sternum with the apex pointing towards the chin and without any covering membrane. It may or may not be associated with the pentalogy of Cantrell. The OMIM web site (Online Mendelian Inheritance in Man, http://www.ncbi.nlm. nih.gov/entrez/dispomim.cgi?id = 313850) lists both as midline defects, part of a possibly X-linked developmental field complex. From the nice three-dimensional ultrasound pictures provided, the case re- ported in the journal appears to be one of the pentalogy of Cantrell with ectopia cordis, which significantly worsens the prognosis.

\section{References}

1 Araujo E Jr, et al: Diagnosis of pentalogy of Cantrell by three-dimensional ultrasound in third trimester of pregnancy. Fetal Diagn Ther 2006;21:544-547.

2 Klein MD: Congenital defects of the abdominal wall; in Grosfeld JL, O'Neill JA, Fonkalsrud EW, Coran AG (eds): Pediatric Surgery, ed 6. Philadelphia, Mosby, 2006, p 1162.

\section{Reply}

\section{Edward Araujo Júnior}

Ultrasound Training Center of São Paulo (CETRUS), Obstetrics Department of Federal University of

São Paulo (Unifesp/EPM), São Paulo, Brazil

Dear Dr. Laberge,

I am very glad for your interest and your comments on our article. About the definition of pentalogy of Cantrell, I am aware that, according to the initial description by Cantrell et al. [Surg Gynecol
Obstet 1958;107:602-604], ectopia cordis is not part of the five malformations of the syndrome. Actually, it was mistakenly included instead of defect of the lower sternum. Ectopia cordis might or might not be associated with pentalogy of Cantrell.

I would like once again to thank you for your comments and for the attention given to our article.

\section{KARGER \\ Fax +4161306 1234 E-Mail karger@karger.ch} www.karger.com
(C) 2007 S. Karger AG, Base $1015-3837 / 08 / 0232-0160 \$ 24.50 / 0$

Accessible online at: www.karger.com/fdt
Jean-Martin Laberge, MD, FRCSC, FACS

Montreal Children's Hospital, McGill University Health Centre

2300 Tupper Street, Room C-1137

PQ H3H 1P3 Montreal, Que. H3H 1P3 (Canada)

Tel. +1 514412 4497, Fax +1 514412 4341, E-Mail jean-martin.laberge@muhc.mcgill.ca 